\title{
Teacher Education System In Indonesia: A Comparative Study
}

\author{
Mohammad Kosim, Faculty of Tarbiyah, State Islamic Institute of Madura (IAIN Madura), Pamekasan, \\ Indonesia,kosim@iainmadura.ac.id
}

Faqihul Muqoddam, Faculty of Psychology, University of Airlangga, Surabaya, Indonesia, faqihul.muqoddam-2018@psikologi.unair.ac.id

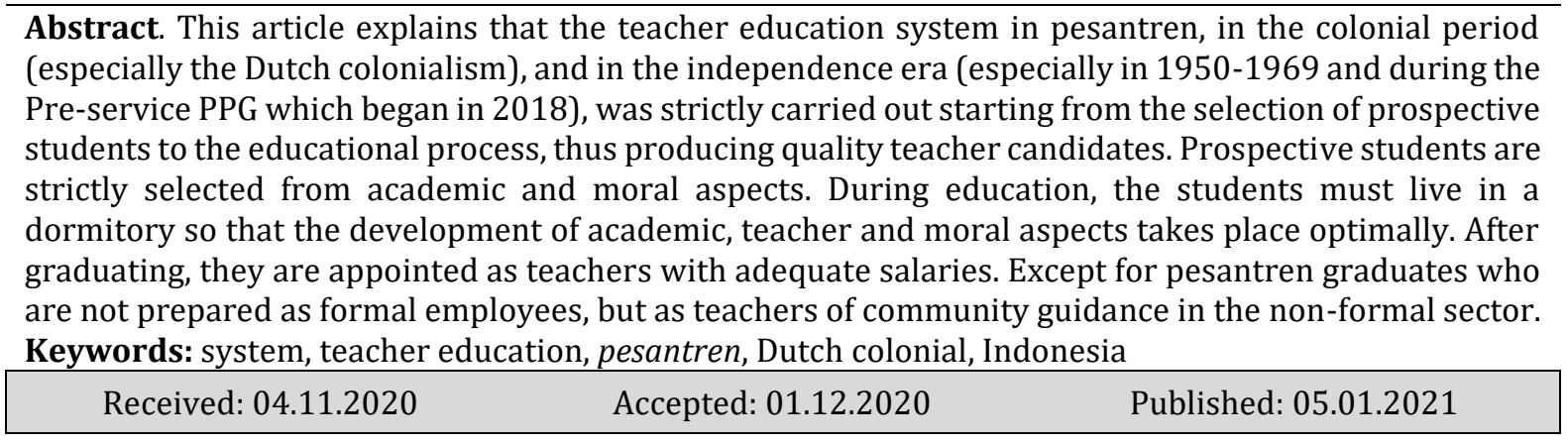

\section{INTRODUCTION}

In the Indonesian education system, teachers' main roles were "to educate, to teach, to guide, to direct, to train, to assess, and to evaluate students "in order to achieve the objectives of national education which was" [1] to develop students "potential to become human beings who believed and had faith in God the Almighty, had noble character, had good health and knowledge, were skillful, creative, independent, and became democratic and responsible citizens"[2]. These provisions represents that teachers were the spearhead of the implementation of education. Without the presence of teachers, education would not take place; without qualified teachers, the process and results of education would not gain a complete success. The concept of a great curriculum would only become a slogan if teacher's abilities were not prepared optimally.

What was qualified teacher? The image of qualified teacher experiences a shift in meaning based on the time demands and development. The results of the study of D.N. Medley described four categories of ideal teacher images; the first category was that teachers who had main personality. In this case, the teachers personify the values that reach mutual agreement; the second one was that teachers who were able to teach properly; the next category was that teachers who were capable to build a positive image within students; and the last one was that teachers who had educator performance that was reflected from the mastery of material, methods, media, and other criteria. From these four categories, the fourth teacher's character was more comprehensive than the other categories [3]. Being qualified teachers was not something that was given but earned, and cannot be attained easily. There were many factors that influence efforts to produce qualified teachers such as the recruitment patterns, teacher training, teacher placement and coaching, and the guarantees of teacher welfare [4]. Based on these factors, the education of prospective teachers had an essential role as an early step in preparing qualified prospective teachers.

Since before independence until now, a number of educational institutions have been known to prepare prospective teachers, both formal and non-formal, including teacher education institutions in pesantren, during the colonial era, and during the independence era. These three teacher education institutions are interesting to study further considering that they have produced many qualified teacher candidates who are taking big roles in the world of education in the country. The main focus of this study is how is the teacher education system in the three institutions? The teacher education system referred to in this study is the pre-service teacher education system. The results of this study were expected to have practical and theoretical uses. Practically, the results could be used to give information for parties who wished to study the teacher education system at the three institutions. Meanwhile, theoretically, the results of this study were expected to enrich the concepts and theories of comparative education which in the global era was increasingly important but in fact, received lack of attention. 


\section{MATERIAL AND METHODS}

\section{The Concept of the Teacher Education System}

A system was a set of things working together as parts of a mechanism or an interconnecting network set [5]. Thus, the teacher education system was an educational interaction of various components in producing the expected teacher candidates. Those components must include at least; educators, students, goals, and methods. In addition, teacher education as a system could also be recognized as an effort to process inputs into outputs and even outcomes. Currently, the teacher education system was organized by universities that were members of the Educational Institute of Teachers' Education (LPTK).

In the operational level, teacher education could be examined from several aspects. From the aspect of teacher preparation and coaching, there were two types of teacher education; pre-service teacher education and in-service teacher education [6]. Pre-service teacher education was a teacher education program followed by students before they become teachers. This kind of education aimed to set the main foundations regarding the knowledge, skills and professional skills and attitudes of prospective teachers. Meanwhile, in-service teacher education was followed by those who had worked as teachers. The aim was to strengthen what they had learnt in pre-service education so that they could carry out their duties effectively.

From the aspect of curriculum content, teacher education could be divided into two, namely general teacher education and competency-based teacher education. The first one emphasized what knowledge the student teacher candidates needed to learn in order to achieve the educational objectives. That purpose of education became the rational foundation of the educational contents. Accordingly, detailed formulations which were then translated into the teacher education curriculum were made. As for Competency-Based Teacher Education (CBTE), the arrangements of the curriculum used technological approach that departed from the competency analysis which was needed to carry out certain tasks. The material taught, the evaluation criteria for success, and the learning strategy were determined according to the task analysis. The CBTE emerged as a reaction to the previous teacher education model which was considered vague and unable to measure how to produce successful teacher candidates [7].

In terms of teacher education providers, it was known that LPTK were autonomous, semiautonomous, and autonomous with a wider mandate. In the autonomy model, LPTK were specifically established to prepare prospective teachers. This model looked like the College of Teacher Training and Education (STKIP) and the Institute of Teacher Training and Education (IKIP). In the semi-autonomous model, LPTK became part of certain tertiary institutions, such as the Tarbiyah Faculty or Education Faculty in Universities. Meanwhile, in the autonomy model with a wider mandate, educational institutions were established with the main task of being LPTK in addition with non-teacher companion programs. This model was demonstrated by the establishment of former IKIP universities such as the State University of Surabaya, State University of Malang, and the Indonesian University of Education in Bandung.

In terms of how to produce teacher candidates, there were two lines of teacher education; concurrent line and consecutive line [8]. Through the concurrent way, from the beginning, students had been educated as prospective teachers through the LPTK. As for the consecutive way, students initially deepened their expertise in non-LPTK tertiary institutions, then continued with studying education and teacher training at the LPTK. Then, according to the history of implementation, the teacher education system was initially carried out traditionally and continued in a modern way. In the traditional era, teacher education was brought about non-formally with simple curriculum which generally emphasized certain norms, such as those practiced in pesantren. In a modern way however, the teacher education system was carried out formally with a well-planned curriculum and was oriented towards modern needs.

\section{METHODS}

This study used a qualitative approach which was a research procedure that produces descriptive data in the form of words, writings, and the behavior of people who could be observed [9]. The type of research was library research because the object studied was a document related to the teacher education system. In addition, this research was included as a historical research because some of the data required came from past events [10]. The steps in historical research generally consisted of four main activities, namely hierarchy, verification, interpretation, and historiography [11].

As a library research, the source of data needed was non-human data in the form of secondary data related to the teacher education system in pesantren, during the colonial period and during the independence era. In collecting the data, the researcher used documentation method which was collecting documents related to the teacher education system mentioned above. As for the data analysis, the researcher used document analysis which was carried out in a comparative manner to understand the 
features of the teacher education system during the periods of pesantren, colonialism, and the independence era.

\section{RESULTS AND DISCUSSION}

\section{Teacher Education System in Pesantren}

Pesantren was the oldest Islamic educational institution in the Indonesia. Long before the existence of madrasah (Islamic school), pesantren had played an active role in educating muslim students and the community development. Historically, pesantren was a combination of Islamic traditions rooted from the traditions of the Prophet Muhammad in Mecca-Medina and indigenous traditions of Indonesia [12]. As an educational institution, pesantren had basic elements that form a pesantren education system which included; kiai (Islamic religious expert and pesantren teacher), santri (the students in pesantren), pondok (boarding house of santri), the kitab kuning (islamic books), and mosque [13]. The purpose of learning in pesantren was solely to conduct the obligation of studying in order to carry out religious orders properly to achieve the blessings of Allah. Focus subject in kitab kuning was contained in classical Islamic books by the ulama (muslim scholars) with the direction of ahl al-sunnah wa al-jamā ah, with characteristics: in the field of tauhid, it follows the opinion of Imam Abu Musa al-Asy'ari and Abu Mansur al-Maturidi, in the field of Fiqh, it follows one of the four theories of Hanafi, Maliki, Syafii and Hambali. Then, in the field of Sufism, it follows Imam Junaid al-Baghdadi and Imam Abu Hamid al-Ghazali [14].

Teaching and learning activities at pesantren were centered in the mosque using the sorogan, bandongan, and ijāzah methods. The sorogan method was individualized method, centered on the santris. In practice, a santri read/memorized the contents of a certain Islamic book in front of kiai, and the kiai listened to the santri and evaluated if there were errors. With this method, before facing the kiai, the santris had really mastered the material so that their reading/memory would not be false or did not had to be repeated. The bandongan method was collective method, centered on the kiai [15]. In practice, the kiai read and explained a certain Islamic book, while the santris - carrying the same Islamic book - listen to him and note important things in their respective Islamic books. Sometimes, before the activity of reading the Islamic book begins, certain santris (one by one) were appointed to read the book that would be studied in several paragraphs. Learning using the sorogan and bandongan methods was carried out continuously until the book being studied was complete, then moving to study another book. After completing the Islamic book, the kiai granted ijāzah as a sign that the santris had finished and mastered the book and also as a form of the kiai's blessing that the santri was worthy of teaching it to others. When granting the ijäzah, kiai usually recited/read the teacher's lineage of the Islamic book from the teachers in chain to the author of the Islamic book. This was what was called scientific sanad (a linkage of narrators who connect to the Islamic book editorial or the narrators of it who conveyed the Islamic book to the people). Through this sanad tradition, the islamic books would be preserved, its authenticity was maintained, its meaning was maintained as intended by the author, and the recipient of sanad had scientific authority related to the Islamic book studied.

There was no time limit on how long santri must learn in the pondok. Due to the former notion, it commonly finds that santri who had learned for a dozen years would still stay in the pesantren. On the other hand, there were also many students who only stayed in a relatively short time. Also, there was no specific test to measure the students' success of learning. The only measure was that the santris' submission to the kiai and their ability to learn from the kiai. Santri who were smart but disobedient to the kiai would not realize the kiai's blessing and meaningful knowledge. Therefore, in the pesantren tradition, obedience to the kiai was the source of obtaining the benefit of kiai's knowledge and blessing [16].

Regarding on the teacher education, pesantrens didn't specifically produce teacher candidates. This traditional institution was better known as the tafaqquh fi al-din (Islamic studies institute) whose main function was to transmit and transform Islamic science, maintenance of Muslim traditions, and reproduction of the intellectual of ulama [17]. However, because of these functions, all santris were directed to become teachers (ustadz/kiai) in guiding the community. For this purpose, some santris were particularly prepared by their supervisor to become teachers. They were selected from senior santris who scientifically master the Islamic books and had praiseworthy morals. These selected santris were particularly educated (takhassus) to master advanced the Islamic books with the sorogan and bandongan methods as well as the continuous development of religious personality in the pondok. They were also offered to did an internship of teaching junior santris. Once they were deemed as worthy educators, the kiai would bestow permission and blessing to the selected santris to teach more people or even to establish an pesantren in another place.

Thus, the main criteria for prospective teachers in the pesantren emphasized the academic aspects and a solid religious personalities. The academic aspect was shown from the mastery of advanced islamic 
books, while the personality aspect was reflected from the persistence of worship, modesty in behavior, simplicity, and submission to the kiai. The pedagogical aspects on the other hand, especially the current well known learning strategies, had not received full attention. The concern to this aspect was more focused on the ethics of the teacher-student relationship in order to produce meaningful understanding. There was no certain time of how long a student had been deemed worthy of being a teacher since it depends on individual abilities and the blessing of the kiai.

In subsequent developments, in line with the modernization of pesantren, the teacher education system had undergone a transformation by adopting a modern education system with the principle of "Maintaining good old traditions and adopting new, better traditions". The traditions of sorogan, bandongan, and ijāzah were maintained and sometimes some new methods were added. The measure of the ability of prospective teacher students was more clear, measured from the level of education, at least senior high school graduates, and those who were selected would be particularly educated. Even nowadays, in a number of pesantren, Ma'had Aly had been established, Islamic universities whose graduates were prepared to become religious leaders who would guide the community. Therefore, prospective teachers/kiai that guide community would mostly emerge from Ma'had Aly[18].

\section{Teacher Education System in the Colonial Period}

The Dutch government had colonized the Hindia Belanda (Dutch East Indies), now was known as Indonesia, for approximately 3.5 centuries (1602-1942). Apart from all the unpleasant effects when colonizing Indonesia, the Dutch government played an instrumental role in introducing a modern education system in the colony. However, the education system had been built was discriminatory segregation (Buchori, 2007), which differentiated the level/quality of education based on social classes. The school for indigenous children was distinguished between ordinary indigenous children and noble indigenous children. Likewise, schools for Dutch/European children or those equivalent to European citizens, were widely divergent from schools for indigenous children. In essence, the education system constructed by the Dutch colonialists was really discriminated, especially for ordinary social class indigenous children. In fact, Nasution made more detailed characteristics of the education system that was developed by the Dutch in the colony, namely: (1) the extraordinary gradualism in the provision of education for Indonesian children, (2) the dualism of education by emphasizing sharp differences between the Dutch and indigenous education, (3) strong central control, (4) the restriction of the indigenous schools objectives, and the role of schools to recruit employees as an important factor in educational development, (5) the principle of concordance, and (6) the absence of systematic educational planning for indigenous children education [19].

The teachers who taught in these schools were formally prepared through teacher training schools. However, because the education system built by the Dutch government was segregative and diverse, the teacher schools developed also varied according to the school. For primary schools for indigenous children, prospective teachers were prepared differently according to the type of school. In class I indigenous primary schools which were called HIS (Hollandsch Inlandsch School), the prospective teachers were educated at the Kweekschool and Hogere Kweekschool (HKS) teacher education institution or at the Hollandsch Islandsche Kweekschool (HIK). For prospective teachers in class II indigenous primary schools which were called Standaard School, the teachers were prepared through CVO (Cursus Volkschool Onderwjzer) which was then called OVVO (Opleiding Voor Volks) and Normaalschool. Whereas the prospective teachers in secondary schools were prepared through the MO Akte (Middlebaar Onderwijz Akte) teaching certificate program, namely MO A for prospective teachers in junior high schools (called MULO/Meer Uitgebreid Lager Onderwijs) and MO B for prospective teachers in senior high schools (called AMS/Algemeene Middlebare School)[20].

Although it was segregative in nature, many people considered that the teacher education system developed by the Dutch government in the colony was quite ideal for the needs of teachers at that time [21]. To be accepted in HIK, for example, prospective students were selected strictly. Only those who passed the Kweekschool exam excellently were admitted to HIK. The length of study was 6 years after primary school. In pursuing their study, students must live in a dormitory so that the personal development of prospective teachers could be conducted intensively. They also received adequate incentives during education period, and when graduated, they were appointed as teachers at schools with adequate salaries. The HIK curriculum emphasized the mastery of three aspects; language, general knowledge, and teaching skills. The third aspects consisted of two parts, theory and practice. The theory section included pedagogy, didactic, and methodic [22]. Meanwhile, the practical part included two stages; the preparatory stage, by teaching in an empty classroom; and the real stage, by teaching in real schools under the supervision of senior teachers. Before the teaching practice began, various preparations were carried out such as writing and drawing exercises on the blackboard and speaking practice which were guided painstakingly by the teachers for students with certain difficulties. Regarding the teacher's patience in guiding students, 
Mochtar Buchori shared his experiences: "I once sat in a class with a friend who stuttered. If he stood in front of the class and had to speak, he could not utter any single word completely and clearly. Until he was drenched in sweat, he still could not speak. He always stuttered. One of our teachers patiently trained him to speak calmly. Then, it was time for teaching practice, that friend of ours could finally speak naturally and fluently"[23].

After the Dutch colonialism, the Japaneses took over to colonize Indonesia for about three years (1942-1945). Despite being in power for a short time, Japan had established some schools like what the Dutch did. However, the educational policies implemented by the Japanese government was different from the Dutch. The Japanese government was more egalitarian in developing the education system in the colonies. Therefore, the heterogeneous and segregative schooling system in the Dutch era was integrated into a single schooling system [24].

To prepare prospective teachers in the schools built, the Japanese government had also established teacher schools, namely Sjootoo Sihan Gakkoo (School Teachers 2 years after the SR), Tjuutoo Sihan Gakkoo (Secondary School Teachers 4 years after the SR), and Kootoo Sihan Gakkoo (High School Teachers 6 years after the SR) [25].. The dormitory system and rigorous selection of teacher candidates developed during the Dutch era were maintained in the Japanese era. However, the nuances of learning were very militaristic and tended to ignore academic aspects. Therefore, according to Mochtar Buchori, the quality of teacher schools in the Japanese era was lower than those in the Dutch era, especially from an academic and pedagogical perspective [26].

The colonial teacher education system was subsequently adopted by the Indonesian nation carefully by establishing similar institutions, particularly by Muslims, to prepare educators for Islamic schools that were being developed. Among the teacher education institutions established in the early years by Muslims were Madrasah Mu'allimin al-Irsyad Jakarta (1913), Madrasah Mu'allimin Muhammadiyah in Yogyakarta (1918), Madrasah Mu'allimat Muhammadiyah in Yogyakarta. (1923), Madrasah Mu'allimin Majalengka, West Java (1923), Kulliyat al-Mu'allimin Al-Islamiyah Gontor (1926), Normal Islam Amuntai Kalimantan (1928), Normal Islam Padang Panjang (1931), Kulliyat Mu'allimat al -Islamiyah Padang Panjang (1937), and the Islamic College in Padang (1931) [27].

\section{Teacher Education System in the Period of Independence}

Post Indonesia's independence in 1945, the previous developed teacher education system was adopted by the government, both by the Ministry of Education (as administrators of general education) and by the Ministry of Religion (as administrators of religious education) to educate Indonesia's young generations. Teacher education institutions that had been held within the Ministry of Education, for prospective elementary school teachers, were Teacher School C (SGC), taken 2 years after primary school; Teacher School B (SGB), 4 years after primary school; Teacher School A (SGA), 6 years after primary school; and Teacher Education School (SPG), 3 years after junior high school. Meanwhile, prospective teachers in secondary schools were prepared through higher education teacher education institutions, namely PTPG (Teacher Education College) and IPG (Teacher Education Institute). These institutions had been removed, and now the existing LPTK within the Ministry of Education were the Teacher Training and Education College (STKIP), the Teacher Training and Education Institute (IKIP), and the Teaching and Education Faculty of the Institute/University.

At the Ministry of Religion, the implementation of teacher education was to prepare candidates for religion teachers in schools and madrasas. This strategy was carried out strictly, especially between 19501969, through the SGHAI (School of Teachers and Judges of Islamic Religion) which then became SGHA and SGAI (Teacher School of Islamic Religion) which later became PGA (Religion Teacher Education). SGHA, as the name implied, had a dual mission, in addition to preparing religious teacher candidates, it also "produced" candidates for employees at the religious courts who at that time still needed a lot of professionals. The unification of the two missions into one institution might be caused by practical considerations due to limited resources. At this time, the number of teacher education institutions was designed according to people's needs. Prospective students were strictly selected and those who could pass the selection process would get governmental position; during the education process, the students lived in dormitories so that the personality of the prospective teachers could be intensively fostered; taking the governmental position, adequate incentives were provided; and after graduating, the respective teacher would be appointed as a public teacher with a fairly high salary [28].

That the government highly concerned to teacher education in the early years of independence was inseparable from the influence of the teacher education system developed by the Dutch colonialist which was oriented towards the quality of graduates. As previously explained, the teacher education system in the Dutch era was quite ideal. Prospective students were strictly selected, the incentives were provided for those who had graduated and they must stay in a dormitory so that their personality development could 
be carried out intensively, and after graduation they would be appointed as teachers with adequate salaries [29].

Unfortunately, that ideal policy had been only applied until 1969 [30]. After that, the education of prospective teachers emphasized the quantity; there was no strict selection of candidate participants, the boarding school system was abolished, and there was no strict control from the Ministry of Religion in the establishment of teacher schools. As a result, teacher education institutions existed without quality control. People's interest towards teacher schools was still higher compared to non-teacher schools. Eventually, graduate teacher candidates with below average qualities had become over supply. Although the level of teacher education had been upgraded from secondary to tertiary education, the impacts on the quality of graduates showed the reverse.

Why had the implementation of teacher education in the Ministry of Religion shifted from quality to quantity considerations? It influenced by several factors; First, the democratization of education that were implemented with compulsory education programs and equitable distribution of education had widened out as well as the increasing public awareness of the importance of education; thus, it required a large number of prospective teachers in a period of rapid time. In order to fulfill the urgent needs, the considerations of teachers' qualities did not receive proper concerns. Unfortunately, although the need for teachers was sufficient, the policy of "producing" teacher candidates still continued indefinitely.

Second, the inclusion of religious and political considerations into the world of Islamic education. For example, during the Old Order era (1945-1965), when the Indonesian Commnist Party (PKI) was actively influencing the people through the establishment of "folks' universities", the Ministry of Religion offset it by establishing many PGA (Islamic Teacher Education) and IAIN (State Islamic Institute) in several regions. Likewise, the Ministry of Religion (especially when K.H. Syaifudin Zuhri was in charge of the Minister of Religion) considered that the existence of IAIN was an absolute element in the nation building [31], so the establishment of IAIN was carried out in many places. With these considerations, the establishment of teacher education institutions occured without control. Consequently, graduates became over-supplied with below average quality. These motifs might continue in the present with different patterns. Thus, as long as Islamic education institutions prioritized these considerations, the quality would always be a dilemma that could not be easily resolved.

Third, due to certain amount of the education budget at the Ministry of Religion, this program had stopped as teacher education with the governmental bond and boarding system could no longer get paid. It was important to understand that since the beginning of independence, the education budget at the Ministry of Religion was still far below the education budget at the Ministry of Education. Although changes in the budget pattern had been made in the State Revenue and Expenditure Budget (APBN), from the religious development sector budget to the education sector budget, the amount was still insufficient to meet the needs of Islamic education development standards. Hence, when the budget did not increase, especially while experiencing inequality from the government, the development of the education of religious teachers would face many obstacles.

In its development, the government continued to strive improving the quality of teacher education through numerous programs such as increasing the level of teacher education. Prospective teachers of Elementary School were prepared through secondary school graduates, teachers of Junior High School were prepared from Bachelor/Diploma 2 graduates, and Senior High School teachers were prepared from a Bachelor/Diploma 4 graduates. Moreover, after the issuance of Law Number 2 of 1989 concerning the National Education System, all prospective teachers were prepared through universities with different programs; Elementary School teachers from Diploma 2 graduates, Junior High School teachers from Diploma 3 graduates, and Senior High School teachers from Bachelor/Diploma 4 graduates.

Apart from going through the LPTK route, teacher education can be pursued through the Teaching Certificate program (Akta Mengajar). This program came into effect in 1979 [32] and ended in 2005 after the issuance of Law Number 14 of 2005 concerning Teachers and Lecturers. The purpose of the Teaching Certificate program is to provide opportunities for non-teacher faculty graduates to gain teaching authority at various schools. In particular, there are two objectives of this deed program, namely (a) to make the teaching profession open to people outside the Teaching faculty, and (b) to provide protection to the educational profession by requiring that everyone who wants to work as a teacher have a teaching certificate [33]. In practice, the teaching certificate program was organized by the LPTK. Non-teacher graduates who follow this deed program must follow a program of 20 credits which contains teacher material (theory and practice).

In fact, increasing the level of teacher education to tertiary institutions didn't bring many positive impacts on the quality of graduates/prospective teachers. This was because LPTK organizers were not selected the participants strictly and did not confine the number of participants. Likewise, there was no strict selection of LPTK student candidates, no boarding houses, and the learning process was also not 
optimal. After graduating, they were not automatically promoted as governmental employees. Therefore, the loosening of inputs and processes would have some impacts on the LPTK graduates who were generally below average quality.

Moreover, after the issuance of Law Number 14 of 2005, the strategies of improving the quality of teachers were carried out by raising the image of teachers to become professional educators and receiving professional allowances. With this provision, the requirements to become teachers would be more complicated because in addition to having to pass a Bachelor/Diploma 4 program, teachers must also pass a competency test to get an educator certificate. On a practical level, teacher competency tests were conducted in stages by prioritizing teachers who already had worked in some particular institutions, through direct certificates, portfolio assessments, PLPG (Teacher Education and Training), and since 2018 it had required to attend the PPG (Teacher Professional Education).

Up to the present, PPG was held for two targets, in-service PPG for working teachers and pre-service PPG for prospective teachers. Relating to the current research, the research target was Pre-service PPG. Starting in 2018, the PPG organizers were PPG Study Program at certain LPTKs that were selectively appointed by the government. Prospective PPG participants were strictly selected with limited number of qualified participants. Referring to the 2019 Pre-service PPG, the selection of PPG participants included three stages; administrative selection (Bachelor/Diploma 4 graduates according to the required formation in an accredited B study program, with a maximum age of 30 years), academic selection, talents, interests, personality, and vocation. The first year of attending the university, students lived in a dormitory so that the strengthening of academic and character building of educators run optimally. The PPG curriculum more emphasized the practice (teacher training) which was implemented in collaboration with selected partner schools. At the end of the PPG program, participants must take a competency test to get a professional certificate as a sign of formal recognition that they had been designated as professional teachers and (when working as a teacher) would receive a professional allowance from the government. With this strict procedure, it was believed that Pre-service PPG graduates would become professional teachers that were competent academically, pedagogically, and personally.

\section{DISCUSSION}

The three teacher education systems; in pesantren, during the Dutch colonial era, in the early years of post independence (1950-1969) and during the Pre-service PPG (starting in 2018) had similar principles in the selection of potential participants and in the educational process to produce qualified teacher candidates based on the needs of each institution in their time. In using the input-process-output system approach, the three education systems really had high concerns to the input and process to produce the expected output because the input quality would facilitate the process, and the optimal process would produce output with absolute quality.

In the teacher education system in pesantren, concerns related to the input aspects were demonstrated by the strict selection of teacher candidates. Only senior santri who had a solid religious personality and mastered kitab kuning were prepared to become teachers. This selected input was processed informally through the sorogan and bandongan method, assignments to foster junior santri, and ijäzah. The requirement for santris to live in a pondok allowed the development of religious personality and mastery of Islamic knowledge to be intensively conducted. This intense process would produce qualified teachers who were ready to serve and help developing the students comprehension.

During the Dutch colonial period, the strict procedures of the teacher education system were shown in the input of prospective students who were strictly selected from physical, personality, and intellectual aspects. This selected input was processed by emphasizing the development of personality, intellectual, and teaching skills through the boarding school system and guided teaching practices. After graduating, the particular prospective teacher would be appointed as an official teacher with an adequate salary. With strict procedures and high respect for teachers, many qualified teachers were competing to register into teacher schools.

Whereas the teacher education system in the early years after the independence day (1950-1969) tended to follow the pioneering work of the Dutch colonialists which implemented strict procedures including for the teachers and the processes with the dormitory system and governmental bond in order to get qualified teacher candidates. After the firm selection process with governmental union, the teacher education system was implemented loosely due to rapid and huge demands for teachers and budget constraints. Besides, since the status of teachers as professional educators increased significantly, especially since the Pre-service PPG in 2018, the teacher education system had begun to be strictly enforced in the selection and process to produce qualified graduates. 
There were several differences of the aspects of teacher personality development. In pesantren, personality development was more specifically focused on the Islamic personality which could be seen in the perseverance of worshiping Allah and noble morals towards teachers and other people. In the Dutch colonial era, the emphasis was on building character in general so that teachers could become exemplary figures. Meanwhile, during the post colonial period, the emphasis was on the nation chacarter building. Also, teacher education in pesantren had not fully concerned to mastering teaching methods, as was done during the Dutch and post colonial period.

Why did these institutions establish strict procedures for providing teacher education? Because they believed that teachers played the main roles of micro education, as what it stated: "no teacher, no education", and teachers were the only source of learning (teacher centered). Facing these challenges, teachers who were academically, pedegogically and personally competent must be prepared. In this modern era, teachers were not the only source of learning, but because of their various roles [34] as trainers, guides, learning managers, participants, leaders, learners, and authors, it required that prospective teachers be competent pedoagogically, academically and personally.

From the previous description, if it was historically mapped, the teacher education system that had been implemented by the government since post-colonial era could be divided into three periods, namely the progress period (1950-1969), the decline period (1970-2017), and the resurrection period (2018present). It was called a progress period because at that time when the nation had just become independent, the government had the courage to organize teacher schools with strict procedures, boarding house systems, and had official ties with the government. Then, it was called a decline period because at that time, the teacher education system was implemented loosely due to a huge demand of gaining the teachers rapidly along with the limited budget. Finally, it was called the resurrection period because the teacher education system at that time was carried out with strict procedures with multiple selection processes through PPG.

Apart from that, during the post colonial period, the levels of teacher education have been classified into three levels of education. The first level, was the multi-strata system which lasted until 1992. In this system, Elementary School teacher candidates were prepared through secondary teacher schools level, Junior High School teacher candidates were prepared through tertiary institutions in the baccalaureate program and as for Senior High School, prospective teachers were prepared through the undergraduate program. The second level, was the uni-strata system (1992-2005). All prospective teachers in this period were prepared through universities with the following provisions; Diploma 2 program for Elementary School teachers; Diploma 3 program for Junior High School teachers, and Bachelor/Diploma 4 program for Senior High School teachers. The third level, was the uni-strata system (2005-present). In this phase, prospective teachers at all levels of education were prepared through college for the Bachelor/Diploma 4 Program, and required to pass the PPG program.

From the previous explanation it is also known that the implementation of the teacher education system is carried out in two ways; concurrent and consecutive. The secondary level teacher education system is carried out concurrently through teacher training schools. At the higher education level, this is carried out through concurrent and consecutive channels. The concurrent pathway was carried out by the LPTK, while the consecutive line was carried out by non-LPTK universities (for fields of study) and continued by the LPTK (for the education and teacher fields). Since the implementation of Teacher Professional Education (PPG), the government has tended to use an expanded consecutive route, namely that every LPTK and non-LPTK graduate who wants to become a teacher must follow and pass PPG. Which of the two paths is better in administering the teacher education system? The two pathways don't guarantee the quality of prospective teacher graduates. What is very decisive, as explained above, is the strict procedure for selecting candidate participants and the rigorous process of educating prospective teachers.

How was the teacher education system in the future? The strict procedures that had been carried out by pesantren, Dutch colonialists, the Indonesian government at the early years of independence and during the Pre-service PPG remained relevant to be adopted by the LPTK in preparing professional teachers as well as taking into account the current conditions and challenges, especially the challenges of the global world that will affect teachers' duties and responsibilities in the future. The challenges mentioned, according to Mastuhu, were challenges copped by the 21st century national education system which were called the challenges of globalization, complexity, turbulence, dynamics, acceleration, sustainability from the ancient to the modern era, connectivity, convergence, consolidation, rationalization, global paradox, and the power of thought [35]. H.A.R Tilaar mentioned three characteristics of 21st century society that would affect the world of education called the technology society, the open society, and the civil society [36]. Meanwhile, Husni Rahim declared three external challenges endured by the world of education, 
especially Islamic education in the future, which were called globalization, democratization and Islamic liberalization [37].

Thus, future teacher candidates should be professional figures who were competent pedagogically, academically, personally and socially, should have high competitiveness and tolerance; and should be able to master technology for the benefit of education in order to achieve the objectives of national education. Quoted Tilaar sentences, the future teacher is someone who has a mature and developing personality; masters science throughout, possesses the skills to arouse students' interest in science and technology, and is able to develop the profession on an ongoing basis [38].

To prepare such teacher figure, it was necessary to design a professional teacher education system. In 2002, the LPTK Rectors issued recommendations on the development of the millenial teacher education systems which included; (1) teacher education required to follow the vision that teachers must be responsive to the ever-increasing demands for quality, (2) teachers must apply international standards so that their graduates could compete in the global era, (3) teacher education must offer programs that were flexible and rich of high quality to deal with the rapid development of society, (4) the teacher education curriculum must integrate theory and practice that produced subliminal experiences. Therefore, the curriculum contents must include experience groups that develop personality, professional insight, mastery of science, mastery of education and praxis, (5) the implementation of teacher education must be restricted to institutions that could truly guarantee the quality of its output, (6) ) the implementation of teacher education must be supported by professional management who cared about quality, was efficient, innovative, and responsive to the demands and development of the profession and society, (7) professional experience was an essential part of prospective teacher education in order to effectively shape their personality and abilities. Therefore, collaboration between schools and teacher education institutions must be maintained that they could provide valuable experience in improving the quality of teacher education, (8) lecturers and teacher education support practitioners must possess above average quality and be selected based on accurate needs analysis, (9) students must be rigorously selected intellectually, physically, and personally so that they produce selected student candidates, (10) Teacher education institutions must be open to avoid the inbreeding process, (11) Teacher education institutions must had complete teaching and learning process facilities, supporting facilities, and facilities. personality development, and science development facilities. Teaching and learning process facilities include large and small classes with all the equipment, laboratories and studios, workshops, libraries, auditoriums, and micro-teaching centers. Supporting facilities include professional practice bureau, computer and information system center, information and communication technology service center, research and study center. Personality building facilities include dormitories, student centers, worship facilities, facilities for developing talents and interests, and facilities for community service activities. Meanwhile, science development facilities include laboratory schools, educational clinics, and research laboratories, and (12) Teacher education institutions need to implement quality control systems and mechanisms consistently and continuously [39].

\section{CONCLUSION}

Long before the independence of Indonesia, a number of teacher education systems had been implemented to produce qualified teacher candidates according to the goals and targets of some particular organizer. Starting with the pesantren, the oldest Islamic education institution in Indonesia, which prepared prospective teachers non-formally at the pesantren, then continued by the Dutch colonialists who introduced a formal teacher education system, and followed by the government during independece period. The teacher education system in the independence period could be classified into three terms; a period of progress (1950-1969), a period of decline (1970-2017), and a period of awakening (2018present).

There was a meeting point for the teacher education system implemented by pesantren, the Dutch colonialists, and by the government, especially during the progress and awakening period, which were strictly held from the selection of participant input to the educational process to produce the output of qualified teacher candidates. In terms of participant input, only those who had good personalities and had above average academic abilities were accepted as students. During the education process, they had to stay in a dormitory (pondok in the tradition of pesantren) so that the teacher personality development, teaching skills, and academic deepening could be carried out optimally. After graduating, they were granted the appointment as government teachers with adequate incentives. In a period of decline, it could be stated that the government had failed in implementing teacher education system to produce qualified teacher candidates. When there was no strict selection of LPTK and prospective participants, there was no boarding 
school system that caused the education process not optimal, and that the graduates didn't receive proper concerns from the government.

\section{REFERENCES}

Republic of Indonesia Law Number 14 of 2005 concerning teachers and lecturers, article 1 paragraph (1) Republic of Indonesia Law Number 20 of 2003 concerning the national education system,

article 1 paragraph (1)

Noeng Muhadjir. Ilmu pendidikan dan perubahan sosial; teori pendidikan sosial kreatif. Yogyakarta, Rake Sarasin, 2000, p. 80-83

Soedijarto. Recruitment, education and placement and teacher fostering to support relevant

and quality of education, in Pendidikan untuk masyarakat Indonesia baru; 70 tahun prof. dr. H.A.R. Tilaar, M.Sc.Ed. Jakarta, Gramedia, 2002.

https://www.lexico.com/definition/system n.d.

Eduwen Friday Osamwonyi. In-service education of teachers: overview, problems and the way forward. Journal of Education and Practice Vol.7, No. 26, 2016, p. 83-87 www.iiste.org; Oemar Hamalik. Pendidikan guru berdasarkan pendekatan kompetensi. Jakarta, Bumi Aksara, 2006, p. 14.

Hugh Field. Competency based teacher education (CBTE): A review of the literature. Journal of In Service Education, 2006, 39-42, https://doi.org/10.1080/0305763790060109; Suryati Sidharto. Pendidikan di negara berkembang suatu tinjauan komparatif. Jakarta: Proyek Pengembangan LPTK, Ditjen Pendidikan Tinggi Departemen Pendidikan Nasional, 1999.

Muchlas Samani, et.al., Mengenal sertifikasi guru di Indonesia. Surabaya, Cooperation of SIC

Publishers and the Association of Indonesian Education Researchers, 2006, p. 27; Zuzovsky and Smadar, Ruth Sch, and Midt. Comparing the effectiveness of two models of initial teacher education programmes in Israel: concurrent vs. consecutive. European Journal of Teacher Education, Vo. 40, 2017, p. 413-431. https://doi.org/10.1080/02619768.2017.1318377

Robert Bogdan and Steven J. Taylor. Metoda penelitian kualitatif. Surabaya, National Enterprises, 1992, p. 21-22.

Dudung Abdurahman. Metodologi penelitian sejarah. Yogyakarta, Ar-Ruzz Media, 2007, p. 53; Louis Gottschalk. Mengerti sejarah, trans. Nugroho Notosusanto. Jakarta, UIP Press, 2006, p. 39

Nugroho Notosusanto. Norma-norma dasar penelitian dan penulisan sejarah. Jakarta, ABRI Historical Center, 1974, p. 17.

Nurcholish Madjid. Bilik-bilik pesantren; sebuah potret perjalanan. Jakarta, Paramadina, 1997, p. 3; Martin van Bruinessen. Kitab kuning, pesantren, dan tarekat; tradisi-tradisi islam di Indonesia. Bandung, Mizan, 1999, p. 21; Karel A. Steembrink. Pesantren, madrasah, dan sekolah; pendidikan islam dalam kurun modern. Jakarta, LP3ES, 1994, p. 20.

Zamakhsyari Dhofier. Tradisi pesantren; studi tentang pandangan hidup kiai. Jakarta, LP3ES, 1994, p. 44.

Abdurrahman Wahid. The Development of ahlus sunnah wal jamaah in the Nahdlatul Ulama environment, in Said Aqil Siradj. Ahlus sunnah wal jamaah dalam lintasan sejarah. Yogyakata, LKPSM, 1997, p. ix.

Ervan Nurtawab. The Decline of traditional learning methods in changing Indonesia; trends of bandongankitab reading in pesantrens. Studia Islamika, Vol. 26, Number 3, 2019. 3, 201: 511-537. https://doi.org/10.36712/sdi.v26i3.11026

Eduwen Friday Osamwonyi. In-service education of teachers: overview, problems and the way forward. Journal of Education and Practice, Vol. 7, No. 26, 2016, p.83-87. www.iiste.org; Oemar Hamalik. Pendidikan guru berdasarkan pendekatan kompetensi. Jakarta, Bumi Aksara, 2006, p. 14.

Directorate of Religious Education and Islamic Boarding Schools, Directorate General of Islamic Religious Institutions, Ministry of Religion of the Republic of Indonesia. Dinamika pondok pesantren di Indonesia. 2005, p. 5.

Regulation of the Minister of Religion of the Republic of Indonesia Nomor 71 Tahun 2015 concerning Ma'had Aly

S. Nasution. Sejarah pendidikan Indonesia. Jakarta, Bumi Aksara, 1995, p. 20.33

I. Djumhur and Danasuparta. Sejarah pendidikan. Bandung: Ilmu, 1976, p. 139-140; Mochtar Buchori. Evolusi pendidikan di Indonesia: dari kweekschool sampai ke IKIP: 1852-1998. Yogyakarta, Insist. 2007, p. 12-13.

I. Djumhur and Danasuparta. Sejarah pendidikan. Bandung: Ilmu, 1976, p. 140; Mochtar Buchori. Evolusi pendidikan di Indonesia: dari kweekschool sampai ke IKIP: 1852-1998, p. 23. Yogyakarta, Insist. 2007.

Mochtar Buchori. Spektrum problematika pendidikan di indonesia. Yogyakarta, Tiara Wacana, 1994, p. 94. 
Mochtar Buchori. Evolusi pendidikan di Indonesia: dari kweekschool sampai ke IKIP: 1852-1998. Yogyakarta, Insist. 2007, p. 23-24.

Mochtar Buchori. Evolusi pendidikan di Indonesia: dari kweekschool sampai ke IKIP: 1852-1998. Yogyakarta, Insist. 2007, p. 25-44.

Ary H. Gunawan. Kebijakan-kebijakan pendidikan di Indonesia. Jakarta: Bina Aksara, 1986, p. 28; Djumhur, I. dan Danasuparta. Sejarah pendidikan. Bandung: Ilmu, 1976, p. 198.

Mochtar Buchori. Evolusi pendidikan di Indonesia: dari kweekschool sampai ke IKIP: 1852-1998. Yogyakarta, Insist. 2007, p. 39-46.

Mahmud Yunus. Sejarah pendidikan islam di Indonesia. Jakarta, Hidakarya Agung, 1976, p. 97-356

Dedi Supriyadi, et.all. Guru di Indonesia: Pendidikan, pelatihan, dan perjuangan sejak zaman kolonial hingga era reformasi. Jakarta, Directorate of Education Professionals, Ministry of Education of the Republic of Indonesia, 2003, p. 38; Mohammad Kosim. Dari SGHAI ke PGA; Sejarah perkembangan lembaga pendidikan guru agama islam jenjang menengah. http://ejournal.stainpamekasan.ac.id/index.php/tadris/article/view/217/208

Dedi Supriyadi, et.all. Guru di Indonesia: Pendidikan, pelatihan, dan perjuangan sejak zaman kolonial hingga era reformasi. Jakarta, Directorate of Education Professionals, Ministry of Education of the Republic of Indonesia, 2003, p. 37

Laporan Lokakarya Out Put PGAN bagi Angkatan Kerja. Jakarta: Center for Religious Education Research and Development Agency for Religion, Ministry of Religion of the Republic of Indonesia, 1979.

Azyumardi Azra \& Saiful Umam. Menteri-menteri agama ri; biografi sosial politik. Jakarta, INIS, 1998, p. 226.

Based on Decree of the Minister of Education and Culture of the Republic of Indonesia No. 0124/U/1979.

Ministry of Education and Culture of the Republic of Indonesia. Pedoman pelaksanaan pola pembaharuan sistem pendidikan tenaga kependidikan di Indonesia. Project for Development and Control of Directorate General of Higher Education Projects, 1981.

Mohammad Surya. Percikan perjuangan guru. Semarang, Aneka Ilmu, 2003, p. 47.

Mastuhu. Menata ulang pemikiran sistem pendidikan nasional dalam abad 21. Jogyakarta, Safiria Insania Press, 2003, p. 9-20

H.A.R. Tilaar. Beberapa agenda reformasi pendidikan nasional dalam perspektif abad 21. Magelang, Tera Indonesia, 1999, p. 281-284.

Husni Rahim. Madrasah dalam politik pendidikan di Indonesia. Jakarta, Logos, 2005, p. 64-66.

H.A.R. Tilaar. Beberapa agenda reformasi pendidikan nasional dalam perspektif abad 21. Magelang, Tera Indonesia, 1999, p. 295-298.

12 LPTK Rectors. Sistem pendidikan tenaga kependidikan abad ke 21, Jakarta, 2000. 